\section{Lembaran Sejarah}

\title{
Same Fate, Different Choices: Decolonization in Vietnam and Indonesia, 1945-1960s
}

\section{PHAM VAN THUY}

Vietnam National University

\begin{abstract}
The purpose of this study is to sketch out the similarities and differences in the process of decolonization in Indonesia and Vietnam during the period from 1945 to the early 1960s, with special attention to the political and economic aspects. Both countries shared similarities in that they were the first countries to declare independence in Southeast Asia from the Japanese and that they were highly revolutionized during the occupation. Both countries had the most violent and complete colonial break in comparison to other Southeast Asian countries. Yet, there were some major differences within the process of decolonization, especially during the final phase. Indonesia opted for a diplomatic peace process and eventually obtained a transfer of sovereignty from the Netherlands in late 1949, while Vietnam continued military struggle against the French until 1954. This resulted in highly different patterns of the economic decolonization, such as the process of nationalization, the government policies concerning foreign investments and the extent of state control over the economy. French businesses in Vietnam were ruined in the North following the withdrawal of French army in 1954-1955. Their remaining assets in South Vietnam were shortly also taken over by the Diem government. Meanwhile, the Dutch continued to dominate the Indonesian economy after the transfer of sovereignty. It was not until the late 1950s that Dutch firms were seized and finally nationalized by the Indonesian government.
\end{abstract}

\section{Abstrak}

Tujuan penelitian ini adalah untuk mengusut persamaan dan perbedaan proses dekolonisasi di Indonesia dan Vietnam pada periode semenjak tahun 1945 sampai pada awal tahun 1960an, dengan perhatian khusus pada aspek politik dan ekonomis. Kedua negara memiliki kesamaan sebagai negara-negara pertama yang menyatakan kemerdekaan dari Jepang di Asia Tenggara serta keduanya mengalami perubahan revolusioner semasa pendudukan Jepang. Kedua negara juga mengalami pemutusan hubungan kolonial yang paling ekstrim dibandingkan dengan negara-negara Asia Tenggara lainnya. Tetapi ada beberapa perbedaan utama dalam proses dekolonisasi, khususnya pada fase terakhir. Indonesia memilih jalur diplomatis yang berakhir pada pemberian kedaulatan oleh Belanda diakhir tahun 1949, sementara Vietnam melanjutkan perjuangan militer terhadap Perancis

\section{Keywords:}

Indonesia;

Vietnam;

decolonization; nationalization; Southeast Asia

Kata kunci:

Indonesia;

Vietnam;

dekolonisasi;

nasionalisasi;

Asia Tenggara 
sampai tahun 1954. Hal ini mengakibatkan perbedaan pola dekolonisasi ekonomi yang sangat signifikan, seperti dalam proses nasionalisasi, kebijakan pemerintah akan investasi asing serta tingkat penguasaan ekonomi oleh negara. Bisnis Perancis di Vietnam hancur di Utara setelah mundurnya militer Perancis pada tahun 19541955. Sisa aset di Vietnam Selatan juga akan diambil alih oleh pemerintahan Diem. Sementara Belanda tetap mendominasi ekonomi Indonesia setelah penyerahan kedaulatan. Baru pada akhir tahun 1950an, firma-firma Belanda diambil alih dan akhirnya dinasionalisasi oleh Pemerintah Indonesia.

Indonesia and Vietnam were the first colonies in Asia to declare independence in 1945 through their armed revolution against the fascist Japanese occupation. The independent Republic of Indonesia was declared by Sukarno and Mohammad Hatta on 17 August, while in Vietnam, on 2 September, Ho Chi Minh read the Declaration of Independence, proclaiming the birth of the Democratic Republic of Vietnam. Shortly after the capitulation of Japan, however, British troops landed in southern Vietnam and then Indonesia as a contingent of Allied forces to disarm the Japanese and repatriate Allied internees and prisoners-of-war. Under the assistance of British forces, the Dutch and the French also landed troops in Indonesia and Vietnam respectively, but for the purpose of restoring colonial rule, which they had surrendered to the Japanese on the eve of the Pacific War.

Aware of heavy losses and hardship that would inevitably arise if their countries immediately precipitated a war of resistance, the Vietnamese and Indonesian leaders attempted to save their fledgling independence by diplomatic negotiations. In 1946, Vietnam constantly signed with France the 6 March Accords and the 14 September Modus Vivendi. In Indonesia, a truce agreement with the Dutch was also initialled at Linggarjati on 15 November 1946. These agreements were widely considered a serious infringement on the two countries' independence proclamation of 1945. This made military conflict in Indonesia and Vietnam in the near future unavoidable. On 19 December 1946, President Ho Chi Minh called upon the Vietnamese for a war of resistance against the French colonialists. After eight years of warfare, on 21 July 1954, the Geneva Agreement was signed, by which the French agreed to withdraw from Indochina.

Meanwhile in Indonesia, initiatives to begin the fight were given to the Dutch, who sought a military victory to enforce the implementation of Linggarjati agreement. Between 1947 and 1949, the Dutch launched two major military offensives, in Dutch historiography known as the First 'Police Action' (20 July 1947 - 4 August 1947) and the Second 'Police Action' (19 December 1948 - 5 January 1949). These military actions resulted in the conclusion of the Renville Agreement of 17 January 1948 and the subsequent agreements at Round Table Conference of 2 November 1949. 
Although the Netherlands agreed the transfer of sovereignty to the United States of Indonesia, the newly independent government had to shoulder a substantial war debt (4.5 billion guilders or \$ 1.1 billion) (Meijer, 1994: 536) in addition to the obligation of guaranteeing the continuing operation of Dutch enterprises. The economic side of the Indonesian revolution only came to an end in the late 1950s, when most of the Dutch firms were taken over by the Indonesian military and labour unions.

In general, the Indonesian revolution can be divided into two episodes, political decolonization (1945-1949) and economic decolonization (19501960). In Vietnam, the process took place somewhat reversely; French entrepreneurs began to transfer their capital out of Indochina since the late 1940s, before the military withdrawal, which took place after the fall of Dien Bien Phu in 1954. The attempt of this paper is to sketch out the similarities and differences in the process of decolonization in Indonesia and Vietnam during the period 1945-1960. Particular attention is given to military struggles and diplomatic negotiations leading to the conclusion of agreements for independence in the two countries. Economic decolonization will be discussed as a separate part of analysis so as to emphasize the divergence in patterns of decolonization in Southeast Asia. The involvement of Americans as a key factor determining the outcome of the war will be also brought into discussion.

\section{Political decolonization}

Soon after the French - Vietnamese Accord of 6 March 1946, the Dutch Lieutenant- Governor General in post-war Netherlands Indies, H.J. van Mook, decided to use this Accord as a model by which the Netherlands and the Republic could reach an agreement. In the 6 March Accord, it was agreed that France recognized the Democratic Republic of Vietnam as a free state, having its own government, parliament, army, and finances and forming part of the Indochinese Federation in the French Union. The Vietnamese government agreed to the landing of 15,000 French troops in northern Vietnam to replace the Chinese Kuomintang army. ${ }^{1}$ These troops were scheduled to be gradually reduced over a five-year period and replaced by Vietnamese Army. Both parties would take necessary steps to end hostilities, to maintain troops in their respective positions, and to create an atmosphere favourable for the immediate opening of friendly and frank negotiations.

1) As decided among Allied Forces, on 14 August 1945, the Chinese Kuomintang army entered North Vietnam with a task to supervise the repatriation of the Japanese Army. The Kuomintang did not recognize Ho Chi Minh's government, but supported the Viet Quoc and Viet Cach, two major Vietnamese non-communist parties. In February 1946, the Kuomintang signed with the French a treaty by which the Kuomintang forces ceded the rights to occupy North Vietnam to French forces. In return, the French gave up certain rights in China to the Kuomintang. 
These negotiations would deal particularly with the diplomatic relations between Vietnam and foreign states, the future status of Indochina, and economic and cultural interests (Le Mau Han (eds), 2002: 41; Logevall, 2001: 138). Such matters were indeed brought into discussion at the conferences in Da Lat in April-May and in Fontainebleau in July-September, but no agreements were reached. To avoid an early war, on 14 September 1946, Ho Chi Minh reluctantly signed with M. Moutet, the representative of French government, the Modus Vivendi, which provided a ceasefire in Vietnam in exchange for a number of economic concessions from the Vietnamese government (Vu Duong Ninh, 2014: 90-97).

Given the fact that over the whole of Indochina, France only recognized the independent status of Vietnam, the Netherlands therefore could also follow suit by acknowledging the Republic's control over a certain part of the Netherlands East Indies (Yong Mun Cheong, 1982: 76). In return, the Republic would agree to be a member of a federal state in Indonesia, which would then join with the Netherlands in a union. On 25 March 1946, Van Mook submitted to the Republican government four articles based on the 6 March Accords. ${ }^{2}$ In his view, only Java would be under the Republic's control. In the Linggarjati Agreement initialled on 15 November 1946, however, the Republican territory also included the island of Sumatra.

According to the Linggarjati Agreement, the Dutch government recognized the Republic as the de facto authority in Java and Sumatra. The Dutch and Republican governments cooperated toward the establishment of a sovereign democratic federal state called the United States of Indonesia (Republik Indonesia Serikat-RIS), which would consist of three states, the Republic, Borneo and the Great East. Territories not willing to join the RIS could decide by democratic processes their own special relationship to the RIS and to the Netherlands. The Dutch and Republican governments cooperated toward the formation of the Netherlands-Indonesia Union, which would set up its own agencies for the regulation of matters of common interests to the member states, specifically the matters of foreign affairs, defence and certain financial and economic policies. The Republic would recognize all claims by foreign nationals for restitution honouring their rights and properties within areas controlled by the Republic. Any dispute arising from the Agreement would be settled by arbitration (Yong Mun Cheong, 1982: 95).

2) The four articles are: 1) with the exception of the territories held by the Allied Military Administration, the Dutch government would recognize the Republic as exercising de facto authority in Java. The Republic would cooperate with the Dutch government in the creation of an Indonesian federative Free State of which the republic would be a partner. 2) The Republic would agree to landing of Dutch troops to implement Allied tasks. 3) Both parties would agree to cease hostilities. 4) The Dutch government would consult with the Republic and representatives of the areas outside Republican control on the political structure of the future Indonesian state and its relations with the Netherlands Kingdom (Smit, 1962: 30-31). 
Although the Linggarjati Agreement had its genesis in the 6 March Accord, it is a mistake to think that with these agreements, Indonesia and Vietnam achieved the same degree of sovereignty. Vietnam had always been a legally status even long before the arrival of the French and Ho Chi Minh did not demand sovereignty over the whole of Indochina. In the Accord, the French made a promise that they would not interfere in the unification of three parts of Vietnam, consisting of Tonkin, Annam, and Cochinchina. Meanwhile, the Indonesians demanded recognition over the whole former Netherlands East Indies, but the Linggarjati Agreement restricted the Republican authority to only Java and Sumatra. Yet both the 6 March Accord and the Linggarjati Agreement were soon broken because of military actions by respectively French and Dutch forces. Nevertheless, the motivation of the French and the Dutch behind these actions were different. French attempted to break the 6 March Accord, while Van Mook sought for the means to enforce the terms of the Linggarjati Agreement.

The military conflict in Vietnam was ignited on 20 November 1946 over the French occupation of Hai Phong and Lang Son in northern Vietnam. Tensions accelerated in December, when French troops brought about massacres and bombing in and around the capital of Hanoi. At once, two ultimatums were also sent to the Vietminh demanding for the handing over the administration of Hanoi to French forces at the latest on the morning of 20 December (Ho Khang, Trinh Vuong Hong, 2001: 188-189). To forestall French assaults, in the late evening 19 December 1946, it was broadcast on radio across the country Ho Chi Minh's appeal for a national war of resistance: "Fight with all the means at your disposal. Fight with your arms, your picks, your spades, and your sticks” (Tonesson, 2009:222). This is generally known as the start of the First Indochina War, which lasted until 1954. Ho Chi Minh and the revolutionary government apparatus subsequently retreated from Hanoi to the northernmost Viet Bac base.

In Indonesia, military conflicts began relatively later. Following the failure in the implementation of the Linggadjati Agreement due to the resistance by the Indonesians, between January and March 1947, the Dutch gradually pushed forth their occupied perimeter to outside the city of Surabaya. At midnight on 20 July 1947, Dutch forces launched the socalled First 'Police Action' (Operatie Product) against the Republican territory. From Jakarta and Bandung two strong divisions moved out to occupy most of West Java. Two other divisions were sent from Surabaya and Semarang to seize the control of East Java and made some encroachments on the Republican territory in Central Java. In Sumatra, units moved out from Medan to capture control of the surrounding plantation areas (Krimp, de Ruyter, 1980: 37-58). The tactical aim of the First 'Police Action' was two-fold: to destroy the major body of the Republic's armed forces and to 
capture the export products, which had been bottled up in the Republicanheld territories. It was so sudden and swift that most infrastructure and plantations were captured by Dutch forces without damage. The Republican government retreated to its capital Yogyakarta in Central Java (Reid, 1974: 112, Yong Mun Cheong, 1982: 131). Britain and America made clear their disapproval of Dutch military actions in Indonesia and therefore on 4 August 1947, the Dutch government ordered a ceasefire. The aftermath of the First 'Police Action' was a period of negotiations between the Netherlands and the Republic leading to the conclusion of the Renville Agreement of 17-19 January 1948. This agreement confirmed a division of Java between Dutch and Republican forces along the so-called 'Van Mook line'. The Dutch took full control over West Java (Kahin, 1952: 228-229).

The first large-scale military offensive of the French against the Vietminh was organized in the Fall-Winter of 1947 by Jean Valluy, commander-in-chief of the French troops in Indochina. The major objective of the offensive was "to close the northern border of Vietnam, seize the Vietminh leaders at their headquarters, and subsequently destroy all their potentials of resistance" (Dang Phong, 2002: 250). Valluy's concept for his offensive, nicknamed Operation LEA, envisioned a combined airborne, amphibious, and overland assault on the Vietminh governmental and military headquarters in Viet Bac. Operation LEA began on 7 October with parachute drop on the village of Bac Kan and vicinity for the task to capture President Ho Chi Minh and the Vietminh commander Vo Nguyen Giap. Two other pincers, consisting of three infantry battalions from Lang Son and an artillery battalion from Hanoi, were moving to Viet Bac. Valluy confidently predicted that after six days all the pincers would be amassed in the centre of Viet Bac and he could end the Operation LEA in victory. Nevertheless, signs of failure were visible on the first day of the operation, when the paratroopers were unable to find the Vietminh leaders. During the next days, they met with fierce armed resistance of the Vietnamese soldiers and guerrillas and were subsequently encircled by Vietminh troops. The northern pincers was delayed by ambushes, blown bridges, fell trees, and demolished roads. The southern pincers, which was moving to the north by the way of river, also encountered cannon fires and before they could bring pressure to bear from the south, the Vietminh had escaped to the northwest. On 19 October, as the southern pincers met the northern task forces retreating from Bac Kan, Operation LEA came to a fruitless end. Although Valluy organized two other offensives against the southern edge of the Viet Bac base in November, like the Operation LEA, French forces failed to capture the Vietminh government apparatus. By the end 1947, the French admitted that their hope for a 'swift attack and swift victory' against the Vietminh was completely futile (Phillip, 1986: 49). 
After the First 'Police Action' of 1947, the Dutch gained more confidence in their strength and believing that the Republican forces could be overcome by a final knock-out blow. In the morning of 19 December 1948, the Dutch broke the ceasefire by launching a second 'Police Action' (Operatie Kraai or Operation Crow) to seize all remaining Republican territory. Dutch parachute troops dropped near Yogyakarta and in the early morning, they captured the Republican capital. Within a few days, all major cities in Java were occupied. The important Republican leaders, including President Sukarno, Vice-President Mohammad Hatta, and Prime Minister Syahrir were arrested and detained on the island of Bangka, off the east coast of Sumatra (Zweers, 1995: 40). Despite fierce armed struggles in North Sumatra and South Sulawesi, the Dutch occupied most of the sparsely populated Outer Islands without much resistance. Militarily, the Dutch achieved all objectivities, but found themselves occupying a much larger area than they could control. The southern hills became a kind of Ho Chi Minh trail along which guerrillas could infiltrate the whole island (Dick, 2002: 169). Again, the United States strongly opposed to the second 'Police Action' as it obviously broke earlier treaties, which the United States had helped negotiate (Vickers, 2005: 111). Under economic pressure from the United States through Marshall Plan aid, the Dutch government passed a resolution in January 1949, demanding the reinstatement of the Republican government (Taylor, 1960: 189).

Negotiations were resumed in May 1949, at which the Netherlands agreed to discontinue military operations and return Jogjakarta to the Republican government, which was in exile in Bangka. Agreement for the transfer of sovereignty was finally concluded at the Round Table Conference held at The Hague in November 1949. The Netherlands recognized the sovereignty of the United States of Indonesia over the former Dutch colonies in the Netherlands East Indies excluding the territory of West Irian (West New Guinea). The question over the political status of New Guinea would be determined through negotiations within a year from the date of transfer of sovereignty (Ide Anak Agung Gde Agung, 1990: 65-70). In fact, Irian Barat remained a dispute between the Netherlands and Indonesia throughout the courses of the 1950s until the territory was finally surrendered to Indonesia in October 1962.

Strikingly, at the time when the Dutch started withdrawing from Indonesia, France decided to escalate the war in Vietnam. The French installed a new government of the State of Vietnam under the former emperor Bao Dai and declared the return of Vietnam's independence to this government. Nevertheless, Bao Dai was not acknowledged by most of the Vietnamese and even the French viewed his government as simply a French puppet regime (Devillers, 1988: 493). On the contrary, the Vietminh 
government received wide support from the population and continued to operate guerrilla war across the country. After the Chinese revolutionary forces succeeded in taking control over China in 1949, the Vietminh gained a political ally and supply area just across the border. In 1950, the Soviet Union and other countries in the socialist camp also recognized Ho Chi Minh as the legitimate ruler of Vietnam.

The recognition of Ho Chi Minh's government by China and Russia was often ascribed for a change in U.S policy on Vietnam. Afraid of the communist expansion to Southeast Asia, the Americans decided to provide aid to French forces to continue the war in Indochina (Patti, 1980: 402-403). The first American aid package was granted on 16 December 1950 with a sum of $\$ 31$ million, equivalent to 10.8 billion piasters. The American contribution in the total war budget of France in Indochina rapidly rose in the following years, from 19\% in 1951 to 50\% in 1952-1953 and 80\% in 1954 (Folin, 1993: 319-320). In accordance, French troops in Vietnam were massively increased from 140.000 troops in 1949 to 460.000 troops in 1954 (Dang Phong, 2002: 257-264). The most skilled generals of the French Army, such as George Revers, De Lattre de Tassigny, and Henri Navarre were also sent to Vietnam. French army strategists now less emphasized large military expeditions against Vietminh's headquarter as they had done in 1947, but more focusing on the consolidation of French forces in North Vietnam. They erected a strategic corridor along Vietnam-China border and the bunker systems in the Tonkin delta in order to encircle the Vietminh and isolate them from China and the inhabitants. Bao Dai was provided with more aid to develop his army, which would assist French forces to ravage and pacify the occupied areas. This is generally known by the French as the 'total war' (guerre totale) and in fact it caused much hardship for the Vietminh.

In order to break the siege, in September 1950, the Vietminh decided to launch the 'Frontier Campaign' (Chien dich Bien gioi) against the French garrisons along the Vietnam-China border. Instead of attacking on Lang Son and Cao Bang, the two most important military posts of French forces at the two sides of their strategically frontier corridor, Vietminh soldiers assaulted the middle post Dong Khe. When the troops from Lang Son and Cao Bang came to rescue Dong Khe, they were all trapped and captured by the Vietminh. Within a month, the Vietminh took control over the northern border areas opening the border to the ally China.

The 'Frontier Campaign' marked the Vietminh's switch over from the defensive to the offensive. Between 1950 and 1952, the Vietminh organized a series of military actions against the French-held territories, notably Tran Hung Dao Campaign (1950), Hoang Hoa Tham Campaign (1951), Quang Trung Campaign, Hoa Binh Campaign (1952), and Tay Bac (Northwest) 
Campaign (1952). The objectives were towns in the Tonkin delta and the northwest mountainous regions. By these campaigns, the revolutionary bases were extended from the mountainous areas to the midlands and the Tonkin delta. In the Winter-Spring Campaign of 1953-1954, the revolutionary forces shifted the attack's directions to southern Vietnam, Cambodia and Laos. A large offensive was also launched against the French camp in Lai Chau, north of Vietnam. This attack forced Navarre, who was appointed as commander of French forces in Indochina in May 1953, to change his plan. Instead of sending reinforcements to the south of Vietnam and other battlefields in Laos and Cambodia, Navarre decided to intensify his forces at Dien Bien Phu in Lai Chau. The total French forces gathered at Dien Bien Phu at the peak were calculated more than 16,000 troops, divided into 49 entrenched fortifications. Both the French and Americans confidently asserted that Dien Bien Phu was 'an inviolable fortress'. Navarre hoped to draw the Vietminh into a large battle at Dien Bien Phu and win a decisive victory.

The Dien Bien Phu Campaign began on 13 March 1954, when a pre-emptive Vietminh attack surprised the French with heavy artillery up the surrounding mountains. The French position grew more untenable, particularly when the advent of the monsoon season made dropping supplies and reinforcements by parachute difficult. With defeat imminent, the French sought to hold on until the opening of the Geneva peace meeting on 26 April. The last French offensive took place on 4 May, but it was ineffective. The Vietminh then began to hammer the outpost with newly supplied rockets. The final fall took seven days from 1 to 7 May during which the French fought on, but were eventually overrun by a huge frontal assault. In the morning 7 May, the Vietminh hoist their flag over Dien Bien Phu, effectively ending the First Indochina War (Le Mau Han (eds), 2002: 104-123).

The significance of the Vietminh victory at Dien Bien Phu was apparent at the simultaneous negotiations in Geneva. On 21 July 1954, France signed the Geneva Agreement, which established a cease-fire and temporarily divided Vietnam with a demilitarized zone along the seventeenth parallel. French forces would withdraw into the South while the Vietminh regrouped in the North. An international commission would monitor the accords and supervise national elections to reunify the country in 1956 (Hall, 2007: 9). Yet such elections never took place because of the subversion by the Bao Dai and his successive governments sponsored by the United States. North Vietnam and South Vietnam only became unified in 1976 after two decades of warfare. 


\section{Economic Decolonization}

Together with the dissatisfaction over the status of West Irian, Indonesia also had to accept far-reaching economic concessions in exchange for the transfer of sovereignty by the Netherlands. The Financial-Economic Agreement (Finec) signed at the Round Table Conference guaranteed that Dutch firms could continue doing business in Indonesia as usual, including the remittance of profits. There was also an obligation for the Indonesian government to consult with the Netherlands on any monetary and financial measures likely to have an impact on Dutch interests, which was a definite limitation of Indonesian sovereignty. Nationalization of Dutch enterprises required mutual agreement, with compensation to be determined by a judge on the basis of actual value. The Dutch Minister of Foreign Affairs congratulated himself that he had secured the maximum protection for Dutch business (Dick, 2002: 171).

The new nation was forced to take over $\$ 1.1$ billion of debts of the Dutch colonial administration, comprising the entire internal debt of 3 billion guilder, plus another 1.5 billion of the 3.5 billion external debts (Meijer, 1994: 536). As long as this debt was not fully paid off, the Dutch government had the right to interfere in Indonesian economic policy. More serious was that the modern, large-scale sectors, constituting almost $25 \%$ of the country's GDP were still dominated by Dutch firms and some British and American multinationals (Higgins, 1992: 51). In 1952, for instance, four Dutch firms handled 50\% of all consumer imports and eight firms handled $60 \%$ of exports (Meek, 1956: 168). It is no exaggeration to say that key sector of the Indonesian economy at the time of the transfer of the sovereignty were still dominated by the Dutch firms. In the words of Haji Agus Salim, the economic side of the Indonesian revolution had yet to begin (Higins, 1957: 2).

Indonesian nationalists were seriously concerned about the domination of Dutch capital in the economy and therefore sought to wrest economic power from the Dutch. The 1945 Constitution of the Negara Republik Indonesia emphasized the importance of state and co-operative enterprises in the economy. Vice-President Moh. Hatta also stated that the slogan 'working together' of the Dutch meant that the country would become an economic appendix of the Netherlands. In November 1945, the government issued the Proclamation on Foreign Property, which stipulated that "all foreign property other than that which our State needs to operate itself will be returned to the rightful owners, and as fair compensation as possible will be paid for property taken over by the state" (Sutter, 1959: 311). All vital enterprises, such as public utilities, the rail and tram network, postal and telecommunications services, banks and mining companies should all become state enterprises (Booth, 1998: 54). Nevertheless, when the priority 
and economic nationalism became subordinate to political aspiration and nation's independence, the Republican government's strategy during the revolutionary period was to accept the inevitable necessity of foreign control over large segments of the economy (Lindblad, 2008:57). The Finec agreement of 1949 was made at the expense of Indonesia; no other ex-colony in Asia had to shoulder such a heavy burden.

Ministers in successive cabinets during the early 1950s were pragmatic politicians, who realized that they could not quickly dismantle the colonial and capitalist economic structure without causing economic dislocation and hardship. Given the weakness of the indigenous capital, they found it necessary to retain the operation of foreign companies, which would provide the training to Indonesian employees, capital and technical assistance for the government's projects. In the speech opening the Parliament on 15 February 1950, President Sukarno made an important declaration concerning the role of foreign capital in the economy, which asserted that foreign capital was of vital importance for the rehabilitation of the economy. In September 1950, Prime Minister Natsir went further by saying that the lack of capital was the cause of economic backwardness of Indonesia (Sutter, 1959: 11-18). He suggested building up a 'national economy', which depended strongly on exporting industrial and agriculture productions. Large enterprises should train Indonesian employees and make them part of technical operations, administration, and the top management (Booth, 1998: 54).

In 1951, the Indonesian government implemented the Economic Urgency Program (or Sumitro Program), which put high priority on the development of industrialization. Small-scale industries, such as rubber remilling, cotton spinning, cement, caustic soda, and coconut flour were strongly encouraged. Foreign capital was allowed to invest in these industries, but under the government's supervision. Another aspect of the Sumitro Program was the Benteng (fortress) program, which aimed to build up an indigenous Indonesian business class. The program reserved certain categories of goods for indigenous Indonesian importers, who were provided with trade credits through the state-owned Bank Negara Indonesia. The rationale was to cut Dutch trading houses out of the lucrative import trade, using the allocation of import licenses. While state enterprises would dominate the "key sectors", importing was thought to suit indigenous business because only working capital was required. Over time, indigenous business could accumulate capital to invest in other sectors. In June 1953, the program was extended to nationalization of $70 \%$ of the import trade (Sumitro Djojohadikusumo (ed.), 1954: 3; Sutter, 1959: 1025-1026). Banks, mining companies, and transportation were also considered important to be nationalized, but the progress was lagging seriously behind the official and population expectations. Until the mid-1950s, Dutch control over vital 
parts of the economy remained largely intact (Lindblad, 2008: 218).

According to John Meek, the Indonesian government in the early 1950s was dominated by a group of pragmatic conservatives, who put high priority on achieving economic sovereignty or Indonesianization of the economy (Meek: 1956: 185). With the fall of the Wilopo cabinet in June 1953, more and more nationalist and socialist-minded politicians entered the parliament. These members of the Partai Nasional Indonesia (Indonesian Nationalist Party) sought to speed up the pace of nationalization. When tensions over the West Irian accelerated in 1956, the government unilaterally abrogated the Round Table agreements of 1949. In December 1957, a large number of Dutch companies were taken over by the labour unions. Formal nationalization was authorized by the Parliament in December 1958 and finally implemented in 1959. At the same time, President Sukarno introduced his 'Guided Democracy' and 'Guided Economy', which resulted in the demise of parliamentary democracy. A new system of government was established in which the president would appoint and lead a consensus cabinet. 'Guided Economy' ushered in a period of increasing hostility towards both domestic private capital and remaining foreign capital. The state-owned basic industries were again stimulated and private enterprises were to be supervised through industry associations. The military actively participated in the management of Dutch enterprises and the operation of national economy.

The main reason leading to the failure of the Dat Lat and Fontainebleau conferences in 1946 was a disagreement between the Vietnamese and French delegations on economic and financial matters. Jean Bourgoin, the President of Indochina Sub-Commission, insisted that Vietnam circulate the same monetary units with other countries in the Indochinese Federation to be issued by Bank of Indochina. The French authority continued to control taxation by which the French commodities would not be considered as imports, but as domestic products within the French Union. French enterprises in Vietnam would have special privileges on tax, employment of labour and estates, imports and exports, as well as the consumption of French goods in Vietnam's market (Hardy: 1998: 807-848). The Vietnamese delegation led by Trinh Van Binh and later Pham Van Dong did not agree with these excessive demands. In September 1946, when Ho Chi Minh was in Paris, he made concessions by signing the Modus Vivendi, which recognized the rights of the French to do business in Vietnam on the same level with all the Vietnamese. The Vietnamese government also agreed to the principles of a common currency and taxation over the whole Indochina. ${ }^{3}$

3) As explained by Ho Chi Minh later, these concessions were necessary, because they would help bring a ceasefire, by which the revolutionary government gained more time to prepare for the resistance (Ho Chi Minh, 1995: 162). 
Despite the apparent willingness of Ho Chi Minh to continue negotiations, in November, French forces still occupied the port of Hai Phong and Lang Son. In the view of G. Chaffard, this action "evidently showed that France had decided to use the policy of violence" (Chaffard, 1969: 36).

Bourgoin's stubbornness concerning economic and financial matters completely came in line with his Plan de Modernisation et d'Equipement de L'Indochine, which he had submitted to the French government in January 1946. In the General Report on Indochina's First Modernization Plan, passed by Paris on 18 September 1948, Bourgoin emphasized that the modernization process should start in agriculture. New land will be cleared; therefore a fertilizer policy is necessary. He proposed building factories for the production of phosphates and nitrogenous fertilizers. Other chemical industries included sulphuric acid, soda, chlorine and glycerines. Heavy industries like chemicals, iron, steel, and aluminium would also be developed, because they "constitute a great country's economic infrastructure" and "are yet lacking in Indochina". A key element in the programme is energy production. Two main energy projects were planned: one in the north, near Haiphong, where coal mining would allow significant power supplies, and the other in the Cam Ranh area, near the sea and the Dalat-Da Nhim hydroelectric plant (Hardy, 1998: 825-827).

The plan estimated that the total cost of Indochina's ten-year modernization (1948-1958) would be 3,198 million piasters (at 1939 value, the equivalent of $\$ 685$ million), with 45 per cent of the sum going into public infrastructure (Tertrais, in: Marc Frey, Ronal D. W. Pruessen, Tan Tai Yong, (eds), 2003: 74). It noted that this sum was already beyond Indochina's means, but France was willing to underwrite some of the expenditure. The program favoured regional companies, which would liaise with a single government, while an all-Indochina company would have to negotiate with five different ones, plus the federal authority. Industrial production would be oriented towards the local market; exports were not ruled out, but the driving force for economic growth would be internal. It was expected that after ten years the output values in Indochina, as well as the average per capita income of the Indochinese people would be doubled (Dang Phong, 2002: 466).

Using economic development to strengthen linkages and associations with Indochina, Bourgoin Plan was designed to emphasize the federal character (Tertrais, in: Marc Frey, Ronal D. W. Pruessen, Tan Tai Yong, (eds), 2003: 74). The plan envisioned a Vietnam without the presence of the Vietminh or any other resistant forces, and as an integral part of the Indochinese Federation in the French Union under the French control. Many attempts of Ho Chi Minh during 1947 to urge for ending the war by negotiations were all ignored. On 10 September 1947, Emile Bollaert, the 
newly appointed French High Commissioner in Indochina, made a speech at Ha Dong, calling it a final offer which "must be rejected or accepted as a whole". He did not offer a truce and he said nothing of independence. He mentioned only liberty within the framework of the French Union. France, he said, renounced control over the internal administration of Vietnam, but neither of the Vietnamese army nor of Vietnamese foreign relations, both of which were to remain in French hands. Bollaert promised that the Vietnamese alone would decide the future of Cochinchina. The French High Commissioner, however, was to be the arbiter among the three Vietnamese regions, and he was to control the federal budget (Hammer, 1966: 213). Bollaert made no mention of the Vietminh, for he was planning an assault to capture the Vietminh leaders at their headquarters by the Operation LEA.

On 20 December 1948, the Vietminh government organized an extended meeting at Viet Bac to discuss countermeasures against Bourgoin Plan. The meeting also reviewed the implementation of economic policies since the war broke out until the French 1947 military offensives. It was emphasized that sabotage actions against the economics of French rule were of particular important to assist military struggles. The population should follow the policy of siege, vandalism, and non-cooperation with the French thoroughly. The most popular slogan during this time was: "Do not join the French army; do not pay tax to the French; do not sell provisions to the French; do not buy French goods" (Dang Phong, 2002: 470). In the large cities and towns, the sabotage aimed at the weapons producing factories, mining companies, food warehouses, post offices, bridges and railway. The Vietminh even organized a committee in charge of destroying French plantations with main objectives were the rubber plantations in the southern areas of Vietnam. The sabotage of the Vietnamese forced the French authorities to maintain considerable amount of troops to guard their factories, mines, and plantations. The French businesses in Vietnam were badly damaged during the first years of the resistance. For instance, the Hai Phong Cement Company annually often produced 250-300,000 tons, but in 1947, the production dropped to 40,000 tons. The Hon Gai Coal Mine Company extracted 26,000 tons in 1947 , while the annual average in the previous years was around 145,000 tons (Dang Phong, 2002: 240).

The Bourgoin Plan called for the investment of more than 3 million piasters into Indochina. Nevertheless, since 1950, when the war in Vietnam developed toward the trend without much optimism for French forces, French companies started shifting operations to other French colonies or to France. In 1950, the Indochina Civil Engineering Enterprise transferred its capital to Senegal. Indochina Forest et des Allumettes (Indochina Wood and Match Company) transferred 30 million francs to buy stock of the Forestry and Match Company in Africa. Banque de L'Indochine (Bank of Indochina) established 
new branches in Arab, San Fransisco, Port Villa, Brazil and Africa. Until September 1950, only one-eight of the value of Banque de L'Indochine's dealings was in China, Indochina and Southeast Asia (before the World War II, the ratio was about 40\% to 47\%). In 1951, the Banque France-Chinoise pour le Commerce et L'Industrie (BFCCI) established branches in Madagascar. After the French defeat in 1954, BFCCI closed its offices in North Vietnam (Dang Phong, 2002: 476).

A more typical example for prevalent attitudes of the French business in Vietnam in the 1950s is the French Colonial and Finance Company (Société Financière Française et Coloniale-SFFC). Founded in 1920, the SFFC soon developed into a powerful finance house participating in more than 30 colonial enterprises. In 1931, 19 of these were in Indochina. The SFFC was in the forefront of Indochina's rubber boom in the late 1920s. The SFFC also had interests in the production of tea, sugar, paper and textiles, as well as property and banking. During the Japanese occupation and the revolution since 1940, the SFFC suffered considerably. Some of its subsidiaries, such as the Société Nouvelle des Phosphates du Tonkin, Société Indochinoise des Cultures tropicales and the Société des Caoutchoucs d'Extrême Orient were almost paralysed after 1945. SFFC's companies were primarily located in Hanoi and Hai Phong, but after 1945, especially in the 1950s, their operations were gradually shifted southwards to Saigon and then away from Vietnam altogether. By 1953 only 23\% of the value of the SFFC's dealings were in Indochina, 42.5\% were in Africa and 34.5\% in France (Hardy: 1998: 836).

As a result of the increasing number of French companies moving out of Indochina, the situation in manufacturing in Vietnam became stagnant in the early 1950s. The French consumption heavily relied on the imported goods under the American aid and the subsidies from the French government. The value of American aid for the French authorities in Indochina in 1952 was 280 billion francs. It increased to 292 billion francs in 1953 and at peak 475 billion francs in 1954 (Dang Phong, 2002: 478-479). The decline of production and the increase of inflated money supplies led to a devaluation of the piaster. From December 1945, the exchange rate of the piaster was fixed at the unrealistically high level of 17 francs. In the early 1950s, the piaster in the back markets devalued to 7 or 8.5 francs. This caused the repatriation of currency from Vietnam to France and speculative trafficking in piasters and eventually undermined the monetary basis of the Vietnamese economy. In 1953, the French government decided to devaluate the piaster to 10 francs (Hardy, 1998: 843). By this method, the French government hoped to attract the investment in its economic plans in Vietnam and to promote the production of export goods. Nevertheless, from 1950, French entrepreneurs were no more interested in the manufacturing sectors. Most of French companies remaining in Vietnam in the early 1950s were import firms. Before withdrawing to the south as stipulated by the Geneva Agreement, 
the French destroyed their factories, machines, weapons, and supplies. When the Vietminh took over North Vietnam, it was estimated that 50 percent of infrastructures and facilities over the region were destroyed. In the two largest cities in the north, Hanoi and Hai Phong, only the power and water plants were in operations (Le Mau Han (eds), 2002: 141). The task of economic rehabilitation and development of North Vietnam after 1954 was associated intimately with the process of the liberation of South Vietnam, unification of the country, and the establishment of socialism in Vietnam.

\section{Conclusion}

In his synthetic article on perspectives on comparing the Indonesian and Vietnamese revolutions, William $\mathrm{H}$. Frederick called the attention of historians to the process and patterns of decolonization (Frederick, in: Taufik Abdulla (ed.), 1997: 281). In fact, this comparison has already been a topic of discourse at meetings between heads of the state of the two countries. In 1947, for instance, in a meeting of the Vietnam-United States Friendship Committee in New York, Prime Minister of the Republican government Sutan Sjahrir explained that Vietnam and Indonesia were following different paths to independence, but emphasized that what was important was their long-term goals for their nations and for the regions (Frederick, in: Taufik Abdulla (ed.), 1997: 272). When President Ho Chi Minh visited Indonesia in February 1959, both he himself and President Sukarno stressed that the Vietnamese and Indonesians shared the same political ideals of struggling against colonialism for freedom and independence (Sukarno and Ho Chi Minh, 1959: 7, 11). ${ }^{4}$ Both called attention to the fact that their countries had begun their struggle in August 1945. While the French tried to suppress the newly independent government in Vietnam, Indonesians were faced with the first and second Dutch military actions. Indonesian sovereignty was recognized on 29 December 1949, but, as Sukarno stressed, "Our revolution is not yet finished. Let us continue our revolution until West Irian is returned under Indonesian sovereignty and let us work hard to achieve a just and prosperous society [...]. This is only possible if capitalism and imperialism are eliminated from our country". Ho Chi Minh replied that his government and the Vietnamese people fully supported the Indonesian struggles to recover West Irian and expected that Indonesians would support the ardent desire of the Vietnamese people to achieve early national reunification (Sukarno and Ho Chi Minh, 1959: 12, 21).

In June 1959, Sukarno ended a world tour by visiting Vietnam for six days. ${ }^{5}$ There, he reiterated that the Vietnamese and Indonesians were

4) Nhan dan 28 February, 1-8 March 1959.

5) Sukarno and Hatta visited Vietnam for the first time on 11 August 1945 in Dalat hinterlands at the invitation of the Japanese General Field Marshal Terauchi Hisaichi. At 
"comrades in arms" (kawan-kawan seperjuangan), who both loved freedom. The Vietnamese and Indonesians were the same when we removed their "political skins" (Sukarno, 1959: 40). ${ }^{6}$ The Vietnamese had already chosen communism as their principal political ideology since the 1930s and the communists became the leading forces of the nation. Meanwhile, in Indonesia the priority was given to the Indonesian Nationalist Party (PNI) led by Sukarno and Hatta, who had proclaimed the Republic of Indonesia in 1945. The communists' attempt to form the Indonesian's People Republic to replace the Republican government failed in September 1948. Two of the most influential leaders of Indonesian communists, Muso and Tan Malaka were murdered in 1948 and 1949 respectively.

While political leaders in Indonesia and Vietnam tend to emphasize the similarities in the decolonization process of the two countries, economic and political historians focus on differences. The predominant view in the literature is that Vietnam had a 'real revolution', while Indonesia did not, or that Vietnam's revolution succeeded whereas Indonesia's failed (Frederick, in: Taufik Abdulla (ed.), 1997: 283, 337). According to Brian May, "Indonesians did not have the moral discipline to create either communism or capitalism" (May, 1978: 411). Differences become more apparent when we distinguish between the political decolonization and economic decolonization. By the Round Table Conference, Indonesia achieved political sovereignty over the former Netherlands East Indies, except Irian Barat. Nevertheless, it took ten years more for the Indonesians to accomplish full economic decolonization and few more years gain hold of West Irian. In Vietnam, the French agreed to withdraw from the country after the fall of Dien Bien Phu and the conclusion of the Geneva Agreement in 1954. Their economic decolonization had already begun in 1950, when French companies increasingly transferred operations away from North Vietnam. The economic decolonization of French capital from Vietnam was rapid, absolute, and voluntary, while in Indonesia, the Dutch companies were slowly and coercively taken over by the Indonesian labour unions and later put under direct military command.

\section{Acknowledgement}

Pham Van Thuy is lecturer at the University of Social Sciences and Humanities, Vietnam National University, Hanoi. This research is funded by Vietnam National University, Hanoi (VNU) under project number QG.16.38.

Dalat, Marshal Terauchi promised them independence of Indonesia but without Malaya, British northern Borneo, and Portuguese eastern Timor. Sukarno was appointed Chairman of the Preparatory Committee for Indonesian Independence (PPKI) with Hatta as vicechairman (Anderson, 1972: 63).

6) Quan doi nhan dan, 23-27 June 1959. 


\section{References}

Anderson, B.R.O' Goman (1972). Java in the time of revolution: occupation and resistance 1944-1946. Ithaca: Cornell University Press.

Booth, Anne (1998). The Indonesian economy in the nineteenth and twentieth centuries: A history of missed opportunities. London: Macmillan.

May, Brian (1978). The Indonesian Tragedy. Singapore: Graham Brash.

Chaffard, George (1969). Les deux guerres au Vietnam. Paris: La Table Ronde.

Dang Phong (2002). Lich su Kinh te Viet Nam, 1945-2000. Hanoi: Social Science Publisher.

Davidson, B. Phillip (1986). Vietnam at war; the history, 1945-1975. New York: Oxford University Press.

Devillers, Philippe (1988). Paris, Saigon, Hanoi; les archives de la guerre, 1944-1947. Paris: Editions Gallimard.

Dick, H.W, Vincent Houben, J.Th Lindblad, and Thee Kian Wie (2002). The emergence of a national economy; An economic history of Indonesia, 1800-2000. Leiden: Allen\&Unwin.

Frederick, William H. (1997). "Brothers of a kind; Perspectives on comparing the Indonesian and Vietnamese revolutions", in: Taufik Abdullah (ed.). The heartbeat of Indonesian revolution. Jakarta: Gramdedia Pustaka Utama, pp. 271-293.

Hall, Mitchell K. (2007). The Vietnam war. New York: Longman.

Hammer, Ellen J. (1966). The struggle for Indochina, 1940-1955. Stanford: Stanford University Press.

Hardy, Andrew (1998). 'The economics of French rule in Indochina; A biography of Paul Bernard (1892-1960)', Modern Asian Studies Vol. 34/4, pp. 807-848

Higgins, B. (1992). All the difference; A development economist's quest. Montreal: McGrill-Queen's.

Higgins, B. (1957). Indonesia's stabilization and development. New York: Institute of Pacific Relations.

Ho Chi Minh (1995). Toan tap Vol.6. Hanoi: National Politics Publishing House

Ho Khang, Tring Vuong Hong (eds) (2001). Lich su cuoc khang chien chong thuc dan Phap 1945-1954. Hanoi: People’s Army Publishing House.

Ide Anak Agung Gde Agung (1990). Twenty Years Indonesian Foreign Policy: 19451965. Yogyakarta: Duta Wacana University Press.

de Folin, Jacques (1993). Indochine, 1940-1955; La fin d'un rêve. Paris: Perrin.

Kahin, George McTurnan (1952). Nationalism and Revolution in Indonesia. Ithaca, NY: Cornell University Press.

Krimp, R., J.J. de Ruyter (1980). Operatie Product, de eerste politionele actie in Indonesië. Breda: S.L.

Le Mau Han (eds) (2002). Dai cuong lich su Viet Nam Vol.III. Hanoi: Education Publisher.

Lindblad, Thomas (2008). Bridges to new business, the economic decolonization of Indonesia. Leiden: KITLV Press.

Logevall, Fredrik (2001). The origin of Vietnam war. Essex: Pearson Education Limited.

Louis, Zweers (1995). Agressi II; Operatie Kraai, de vergeten beelden van de tweede politionele actie. Den Haag: SDU.

Meek, John P. (1956). The Government and economic development in Indonesia, 1950- 
1954. Charlottesville: University of Virginia.

Meijer, H. (1994). Den Haag-Djakarta; De Nederlands-Indonesische betrekkingen 19501962. Utrecht: Het Spectrum.

Meuleau, M. (1990). Des Pionniers en Extrême-Orient: Histoire de la Banque de l'Indochine, 1875-1975. Paris: Librairie Arthème Fayard.

Nhan dan, 28 February, 1-8 March 1959.

Patti, L.A. (1980). Why Viet Nam? Prelude to America's albatross. Berkeley: University of California Press.

Quan doi nhan dan, 23-27 June 1959.

Reid, Anthony J.S. (1974). Indonesian national revolution 1945-1950. Melbourne: Longman.

Smit C. (1962). De liquidatie van een Imperium: Nederland en Indonesia 1945-1962. Amsterdam: De Arbeiders Pers.

Sukarno, Ho Chi Minh (1959). State visit to Indonesia of the President of the Democratic Republic of Vietnam, Dr. Ho Chi Minh. Djakarta: Ministry of information Republic of Indonesia.

Sukarno (1959). Presiden Repoeblik Indonesia di Vietnam, 24 Juni-29 Juni,1959, Djakarta: Pemuda.

Sumitro Djojohadikusumo (ed.) (1954). The government's program on industries: A progress report. Jakarta: Institute for Economic and Social Research, Djakarta School of Economics, University of Indonesia.

Sutter, J.O. (1959). Indonesianisasi; Politics in a changing economy, 1940-1955. Ithaca, N.Y. Cornell University Press.

Taylor, Alastair M. (1960). Indonesian Independence and the United Nations. Ithaca: Cornell University Press.

Tertrais, Hugues (2003). "France and the Associated States of Indochina, 19451955”. In: Marc Frey, Ronald W. Pruessen and Tan Tai Yong, (eds), The transformation of Southeast Asia international perspectives on decolonization. Armonk: M.E.Sharpe, pp. 72-82.

Tonnesson, Stein (2009). Vietnam 1946; How the war began. Berkely: University of California Press.

Vu Duong Ninh (2014). Lich su quan he doi ngoai Viet Nam, 1940-2010. Hanoi: National Political Publishing House.

Vickers, Adrian (2005). A history of modern Indonesia. New York: Cambridge University Press.

Yong Mun Cheong (1982). H.J. van Mook and Indonesian independence, A study of his role in Dutch-Indonesian relations, 1945-1948. The Hague: Martius Nijhoff. 